\title{
VIEWS OF THE THINKER AND THE OWNER ON MANAGEMENT
}

\author{
Tuychiyeva Sayyora Suyarkulovna ${ }^{1}$ \\ ${ }^{1}$ Associate professor of the Department "Organization and \\ Management of Cultural and Artistic Institutions" \\ of the Uzbekistan State Institute of Arts and Culture, doctor of philosophy
}

ABSTRACT

There are about seven billion people on earth, and only more than two hundred of them have their own state. The antiquity of the state system is a characteristic feature of the Uzbek people. The well-known figures who created the system of formation, development, improvement and practice of the system of governance testify to the ancient history of this nation. In the effective work of the administration, the enlightenment reforms of the heads of state have certainly made a worthy contribution to the enlightenment of culture and the arts, and this has always been recognized. The unrest, which threatens the peace and tranquility of the country, and the bias in the country's domestic and foreign policies, in turn, have shaped the attitudes of prominent scholars, clerics, poets, and writers about leaders.

Keywords: Institution, scientific institution, scholar, Eastern thinkers, academy, civilization, management, constitution, council, citizen, creativity, criterion of justice.

\section{INTRODUCTION}

There are about seven billion people on earth, and only more than two hundred of them have their own state. The antiquity of the state system is a characteristic feature of the Uzbek people. The well-known figures who created the system of formation, development, improvement and practice of the system of governance testify to the ancient history of this nation. In the effective work of the administration, the enlightenment reforms of the heads of state have certainly made a worthy contribution to the enlightenment of culture and the arts, and this has always been recognized. The unrest, which threatens the peace and tranquility of the country, and the bias in the country's domestic and foreign policies, in turn, have shaped the attitudes of prominent scholars, clerics, poets, and writers about leaders.

The services of scientific intellectuals and well-known talents are also emphasized in the administration. For example, the activities of the brave commander Jaloliddin Manguberdi and Sheikh Najmiddin Kubro, a contemporary of the Temurid prince and minister Alisher Navoi.

A special place is given to the unique scientific views of Aristotle, a world-renowned encyclopedic thinker who made a great contribution to the development of science, and the research of Abu Nasr Farobi (873-950), one of the founders of the Greek school of wisdom. Alloma writes that the first recognition of management is "the ability to make effective use of them (subordinates) by giving everyone a worthy task, depending on their talents and skills". According to the thinker, the main task of the manager is analysis and comparison, constant observation.

This is the reason why the scholar acknowledged that "good deeds can be achieved only if the training and purification of the Spirit continues." [Forobiy; 2016:280].

In the works of the thinker, it is repeatedly emphasized that the three criteria that form the basis of the development of governance are the activities of a virtuous society (ie, an enlightened society), a just system (ie a system based on justice and fairness) and a just leader (only a leader who upholds truth and justice). .

"Man cannot create everything he needs on his own, he needs the services of people of different professions to find them. Other people will be in the same situation. People will need to unite in community and community to meet their needs and find perfection. In this community, each person learns professions according to their nature, talents and abilities, and strives for perfection in their art (profession) every day. Therefore, people living in different places (belonging to different nationalities and religions) unite into different societies. , some will be incomplete.

\section{MAIN PART}

Full communities are of three types: large community, medium community, and small community. A great society is a community of all the places on earth and the people who live there. The average society is a nation. A small community is an association of residents of a city. Incomplete communities are rural, neighborhood, and family communities. The family is the smallest community. The neighborhood and the village belong to the city, and the village community serves the townspeople (to deliver the product). The neighborhood is part of the city, the street is part of the neighborhood. The city is part of the country. Nations are a world community of different countries. " [Forobiy; 2016:238].

What is the role of culture in the development of Farobi society? "("A book on the foundations of 
the views of the people of Fazil "), “Kitabas-political-culture and yurafubima bodial-being "(“Book of policy on cities, it is known as the beginning of existence "), A Word on the Right of the People and the Right to Urbanize "and" A Book on Social and Cultural Affairs "(“ A Book on City Meetings "). The essence of the works is a common description of the scholar's concepts such as "culture", "al-madaniya", "al-madanat", "almadaniy" with the life of society, people's attitudes and qualities. [Forobiy; 2016:280]

"A cultural society and a cultural city (or country) is such that everyone from the population of that country is free in the profession, everyone is equal, there is no difference between people, everyone is engaged in the profession they want or choose. People will be truly free. There will be no sultan (i.e. king) who interferes with the peace and freedom of the people. Between them there are various good habits, pleasures. There will be no absolute leader or chief executive elected from among them. They will be the most noble, tested, worthy of guidance, raised among men. Such leaders therefore liberate their constituents completely, protecting them from an external enemy. Such leaders treat everyone equally, even putting the interests of all above their own interests, sacrificing their personal interests for the benefit of the common good, and spares no effort and wealth for the benefit of the people, "he said. [Forobiy; 2016:284]

It should be noted that in Farobi's views, the role of cultural knowledge in society is a priority, the unifying cultural science of all the good qualities inherent in human beings, the priority of which is to unite society only with cultural knowledge.

When we reflect on Farobi's views on governance, we see that another statesman, the great commander, also created a great school in world military and administrative policy through global reforms in governance.

Another brilliant figure who created the system and practice of formation, development, improvement of the people's system of governance - Hazrat Sahibkiran - Amir Temur Taragay Bahodir oglu (1336-1405) is an invaluable scientific and spiritual heritage of the Muslim East. History confirms that Amir Temur's "Temur's Statutes", which ruled in 27 Eurasian countries by faith, were the main encyclopedia of the XI-XU centuries. This work, which has been analyzed and compared in the society from the big problems of governance to the smallest ones, has been described and decorated for centuries, and has gained the recognition of experts called manaman.

That is why the First President Islam Karimov said: We have no right to do so without propaganda". [Karimov; 1998:4]

We know very well that a skilled leader and a famous commander followed four things in governing the state:

1. Kengash;

2. Tip;

3. Entrepreneurship and vigilance;

4. Caution.

\begin{tabular}{|c|c|}
\hline 1. & Supporting Islam everywhere and at any time; \\
\hline 2. & Management through consultation, consultation, advice, and patient compromise; \\
\hline 3. & $\begin{array}{l}\text { To conduct the affairs of the kingdom on the basis of order, that is, according to the rules and } \\
\text { regulations. }\end{array}$ \\
\hline 4. & Strict management of public affairs; \\
\hline 5. & $\begin{array}{l}\text { Based on the principle of justice and fairness, to "judge both the sinner and the innocent" with } \\
\text { justice; }\end{array}$ \\
\hline 6. & Thrift, ingenuity in the management of the kingdom; \\
\hline 7. & Sayyids and wise men, to place the honor of the muhaddithin; \\
\hline 8. & Acting with determination; \\
\hline 9. & To be aware of the state of the people, to see the elders as fathers, the younger ones as children; \\
\hline 10. & Respect for all people and nations; \\
\hline 11. & Living in harmony with friend, foe; \\
\hline 12. & Friend, respect the soldiers despite their hostility. \\
\hline
\end{tabular}

In this regard, Amir Temur's unique work, such as the provision of well-known people in the field of science and enlightenment, the creation of opportunities for them, their high appreciation in society, the use of their advice and guidance in the development of the state is also noteworthy. 
For Amir Temur, three main qualities have been the criteria of state governance. Amir Temur compares justice in two ways: it is the justice of the leader in words, or speaking from the point of view of truthfulness, and he considers hypocrisy to lie to the people or to say two different things. The next analogy is the principle of justice in work, justice in the activities of the leader. In the time of Temur, loyalty to religion, trust was the basis of faith. Just as a commander demanded faith from himself, so did all his commanders, ministers, and even an ordinary soldier. It is important to note that a just ruler considered it necessary to set a personal example before demanding any quality from his staff.

The just ruler also made positive contributions to the use of educated people in the development of the kingdom, to the promotion of their exemplary life and creative ways. Knowledge and creativity are another of the main criteria. That is why Samarkand, the capital of Movoraunnahr, has become a magnificent center for the development of culture and art. In addition, the sculptures of the world's most powerful artists, painters and architects are reflected in the buildings built in Samarkand. That is why Amir Temur wrote: "If I cut down a tree, I planted ten trees instead", or "Let those who doubt our power look at the buildings we have built."

It is clear from this that Hazrat Sahibkiran had programmatic justice, courage and eloquence. Anyone who reads the "Regulations" will certainly be impressed by the 12 main resolutions of the great ruler:

\section{* Leader's word and deed unity.}

* The leader should be someone to consult for critical advice;

* The order, directive, instruction is personally in the hands of the first leader;

* The decision of the leader is firm and there is no room for debate;

* The decision, instruction, order of the leader must be executed.

* Never, under any circumstances and under any circumstances, a leader must entrust his duties to anyone;

* Listening to the opinion of others, but the leader acting on his own opinion;

* The leader should never forget that the needs of the army and the people are the priorities;

* The words, deeds, decisions, judgments, incentives and punishments of the ruler must be great;

* The manager's work without any pressure and coercion is a sign of his freedom and inviolability. The leader must be inviolable;

* Leadership means leadership. The leader should not have a partner or job trainer;

* Manager's advisors should always be in control.

The following words of the great commander are proof of what we have written:

"Whoever builds a desert, or builds a ditch, or a garden, or a land that is in ruins, let him take nothing from it in the first year, let him take what he has given with the consent of the people in the second year, ", Or" Let the professionals and the enlightened be given jobs from the enterprises of the kingdom, "or" I have taken the scales of justice in my hands, I have done neither less nor more, I have made everyone equal. "

\section{CONCLUSION}

The study of the legacy of eminent scholars, the recognition that they set out valuable directions for the management of national statehood in the development and progress of the native East, is still exemplary today. In particular, their recommendations for the development of culture and the arts should be programmatic for future leaders. After all, the development of any country is decided by knowledgeable and enterprising personnel.

\section{REFERENCES}

[1] Abu Nasr Faroobi. "City of noble people". Tashkent. New generation, 2016.

[2] AmirTemur. "Temur's rules". Tashkent. Uzbekistan.2011.

[3] Karimov I.A. Amir Temur is our pride. On the way to spiritual growth - Tashkent. "Uzbekistan", 1998, 4-5 p.

[4] Nizomulmulk. "Siyasatnoma”. (Siyarul-muluk.). Tashkent. New Century Generation 2017.

[5] Yusuf Khos Hojib. "Kutadg'u bilig". Tashkent. Science. 1971.

[6] Yuldashev M. Synonymic Words in AbdulhamidSulaymonCho'lpon's Works. The International 
journal of analytical and experimental modal analysis. ISSN No:0886-9367. Volume XII, Issue VI, June/2020. PageNo: 1732-1739.

[7] Irgashevich, D. A. (2020). Development of national network (tas-ix). ACADEMICIA: An International Multidisciplinary Research Journal, 10(5), 144-151. Article

http://dx.doi.org/10.5958/2249-7137.2020.00254.2 